(c) American Dairy Science Association, 2003.

\title{
Comparison of Feeding Corn Silages from Leafy or Conventional Corn Hybrids to Lactating Dairy Cows ${ }^{1}$
}

\author{
T. D. Nennich, ${ }^{* 2}$ J. G. Linn, ${ }^{*}$ D. G. Johnson, $\dagger$ M. I. Endres, ${ }^{*}$ and H. G. Jung ${ }^{\star, \ddagger}$ \\ *Department of Animal Science, University of Minnesota, St. Paul, MN 55108 \\ †West Central Research and Outreach Center, University of Minnesota, Morris, MN 56267 \\ ‡USDA-Agriculture Research Service, St. Paul, MN 55108
}

\section{ABSTRACT}

Three corn hybrids (Pioneer 36F30, Mycogen TMF2450, and Mycogen TMF2404) were compared for yield and quality traits, and lactation performance and apparent digestibility by Holstein cows. The three corn silages were harvested at a target of 33 to $35 \%$ dry matter. Before harvest, six corn plants were randomly selected for plant fractionation. Grain-to-stover ratios were $0.92,0.70$, and 0.95 for the 36F30, TMF2450, and TMF2404 corn plants, respectively. Fifty-two multiparous Holstein cows were placed on a 120-d lactation trial after a 21-d covariate diet. Cows were blocked by calving date and randomly assigned within block to one of three dietary treatments, containing approximately $40 \%$ (dry matter basis) corn silage. Milk yield, milk components, and dry matter intake did not differ among dietary treatments. In vitro true and neutral detergent fiber digestibilities were numerically higher for TMF2404 than the other corn silage hybrids. Apparent total-tract crude protein and neutral detergent fiber digestibilities, as measured by acid insoluble ash, were higher for TMF2450 than the other two hybrids, but starch digestibility was not different between the corn silage dietary treatments. Although small differences in nutrient content and digestibility existed among corn silage hybrids, inclusion of these leafy hybrids in lactating cow diets at $40 \%$ of the dietary dry matter did not have a significant impact on lactation performance of dairy cattle.

(Key words: corn silage hybrid, dairy cow, nutrient digestibility)

Abbreviation key: $\mathbf{C O V}=$ covariate corn silage, $\mathbf{E E}$ $=$ ether extract, IVTD = in vitro true digestibility, IVNDFD $=$ in vitro NDF digestibility, $\mathbf{N D I C P}=$ neutral detergent insoluble CP.

\section{INTRODUCTION}

Corn silage is a major feed ingredient in many diets fed to dairy cattle, and its use in lactating cow diets

\footnotetext{
Received November 25, 2002.

Accepted April 3, 2003.

Corresponding author: J. G. Linn; e-mail: linnx002@umn.edu.

${ }^{1}$ Mention of a trade name, proprietary products, or specific equipment does not constitute a guarantee of the product by the University of Minnesota or the USDA-ARS, and does not imply its approval to the exclusion of other products that may also be suitable.

${ }^{2}$ Current address: Washington State University, Puyallup, 7612 Pioneer Way, Puyallup, WA 98372; tnennich@wsu.edu.
}

continues to increase. There are several different types of corn hybrids to consider for use as silage in dairy cattle diets including waxy, high lysine, brown midrib, high oil, and leafy hybrids. Recently, selection of corn hybrids for silage has increasingly emphasized improved NDF digestibility in addition to high grain content and overall DM yield.

There are numerous lactation studies comparing different corn silage hybrids (Barriere et al., 1995; Oba and Allen, 1999; Kuehn et al., 1999; Bal et al., 2000; Ballard et al., 2001; Thomas et al., 2001; Clark et al., 2002). Of the available corn silage hybrid types, the brown midrib trait is the only one that consistently shows an improvement in milk production (Oba and Allen, 1999; Bal et al., 2000; Ballard et al., 2001). Several studies have reported small or no differences in milk production when leafy corn silage hybrids were fed to lactating dairy cows (Kuehn et al., 1999; Bal et al., 2000; Ballard et al., 2001). However, two studies (Thomas et al., 2001; Clark et al., 2002) have reported significant increases in milk production from feeding leafy corn silage hybrids compared with conventional corn silage hybrids to lactating dairy cows. Inclusion of leafy corn silage hybrids in dairy cattle diets often has not increased DMI over diets containing conventional corn hybrids (Kuehn et al., 1999; Bal et al., 2000; Thomas et al., 2001); however, Ballard et al. (2001) did find that Holstein heifers ate more of a leafy corn silage hybrid than a conventional hybrid, and Clark et al. (2002) observed higher DMI by midlactation Holstein cows fed diets containing a leafy corn silage hybrid than those fed diets containing conventional corn silage hybrids.

Although previous research has not shown a consistent increase in milk production or DMI from feeding a leafy corn silage hybrid, new and/or improved corn silage hybrids are introduced to the market each year. As new hybrids are developed, it is important to evaluate their agronomic traits and to determine the effects of new hybrids on dairy cattle performance. Mycogen Seeds (Dow AgroSciences, Indianapolis, IN) developed a new leafy corn silage hybrid, TMF2450, which they reported was selected for both increased NDF and starch digestibility. The objective of this study was to evaluate this new leafy corn hybrid against a conven- 
tional corn hybrid and an earlier generation leafy corn hybrid for nutrient composition and digestibility and DMI and lactation performance of dairy cows.

\section{MATERIALS AND METHODS}

\section{Corn Silages}

A conventional corn hybrid (Pioneer 36F30) and two leafy corn hybrids (Mycogen TMF2404 and TMF2450) were planted at the University of Minnesota West Central Research and Outreach Center at Morris. The seeding rate for 36F30 and TMF2450 was 83,980 plants per hectare, whereas 74,100 plants per hectare were planted for TMF2404. The lower seeding rate for TMF2404 was per Mycogen Seeds recommendation for this hybrid. Planting dates were April 27, 2000, for 36F30 and May 2, 2000, for both TMF2450 and TMF2404. Fields were fertilized according to soil test results and were cultivated before planting.

A target of 33 to $35 \%$ whole plant DM and a kernel maturity of half milkline were set as targets for harvesting. However, actual kernel maturity was two thirds to full milkline when the corn silage hybrids reached the correct whole plant moisture levels. Corn silage hybrids were harvested on September 7, 8, and 11, 2000 (36F30, TMF2404, and TMF2450, respectively). The corn silages were harvested with a conventional forage harvester, without a kernel processor at a $0.95-\mathrm{cm}$ theoretical length of cut. Yields for each of the corn silage hybrids were estimated by averaging the weights of individual wagonloads from measured areas of the field. Silages were fermented for a minimum of $35 \mathrm{~d}$ in 2.35$\mathrm{m}$ diameter plastic silage bags (Ag-Bag, Int., Warrenton, OR) before the start of the feeding study.

Six plants from each hybrid were randomly selected from the fields before harvest. The plants were separated into three fractions: grain, stover, and cob plus husk. The individual plant parts were dried at $60^{\circ} \mathrm{C}$ in a forced-air oven to determine DM percentage and grain-to-stover ratios for each hybrid. Nutrient composition of the three corn silages was estimated for diet formulation with mini-silos. Mini-silos constructed of polyvinyl chloride pipe $(10 \mathrm{~cm}$ in diameter by $35.5 \mathrm{~cm}$ tall) were packed with chopped whole corn plant material using a mechanical press and sealed on each end with a rubber cap and clamp. Gas was vented from the mini-silos via a small hole in one of the rubber caps that was fitted with a glass tube sealed with a slit rubber stopper. Six mini-silos were prepared for each hybrid from randomly collected samples of chopped silage throughout the harvest. Each silo contained approximately $2.2 \mathrm{~kg}$ of wet silage. Silos were allowed to ferment for $28 \mathrm{~d}$ before opening and compositing by hybrid. A sample from the mini-silo composite for each
Table 1. Ingredient composition of diets containing covariate (COV), Pioneer 36F30, and Mycogen TMF2450 and TMF2404 corn silages.

\begin{tabular}{lrrcc}
\hline & \multicolumn{4}{c}{ Diet } \\
\cline { 2 - 5 } Ingredient & COV & 36F30 & TMF2450 & TMF2404 \\
\cline { 2 - 5 } & \multicolumn{4}{c}{ \% of DM } \\
\cline { 2 - 5 } Corn silage_covariate & 40.9 & 0.0 & 0.0 & 0.0 \\
36F30 corn silage & 0.0 & 40.6 & 0.0 & 0.0 \\
TMF2450 corn silage & 0.0 & 0.0 & 40.4 & 0.0 \\
TMF2404 corn silage & 0.0 & 0.0 & 0.0 & 40.7 \\
Alfalfa haylage & 19.3 & 14.5 & 11.9 & 16.3 \\
Ground corn & 13.4 & 18.3 & 20.1 & 18.3 \\
Soybean meal & 6.9 & 8.4 & 8.5 & 7.4 \\
Distillers grain & 7.0 & 5.1 & 6.0 & 4.2 \\
Grain mix & 12.5 & 13.1 & 13.1 & 13.1 \\
\hline \multicolumn{1}{l}{ 1. }
\end{tabular}

${ }^{1}$ Ingredients of grain mix are shown in Table 2.

corn silage hybrid was analyzed by near infrared spectroscopy (Dairyland Laboratories, St. Cloud, MN) to determine nutrient composition for formulation of diets fed in the lactation study. Subsamples from the minisilo composites were also tested for in situ starch digestibility using a rumen-fistulated cow fed a corn silage based TMR. Fifteen grams of corn silage (DM) was placed, without drying or grinding, into polyester in situ bags $(25 \times 35 \mathrm{~cm})$. Bags were placed in the cow at $1200 \mathrm{~h}$, approximately $8 \mathrm{~h}$ after feeding, and incubated for $16 \mathrm{~h}$. Blank bags were included to correct for influx of starch into sample bags. Bags and residue were thoroughly washed by hand and dried in a $60^{\circ} \mathrm{C}$ forced air oven. The residue was then ground through a 1-mm cyclone mill (Udy Co., Fort Collins, CO) and analyzed for starch as described below.

\section{Lactation Study}

Cows and diets. The lactation study was conducted from September 25, 2000, through July 15, 2001, at the West Central Research and Outreach Center, Morris, Minnesota. All cows were managed and cared for according to University of Minnesota Institutional Animal Care and Usage Committee recommendations (Animal Subjects Code 0010A69761). Multiparous Holstein cows were housed in a tie-stall barn and placed on a covariate diet immediately after parturition (Table 1). Cows remained on the covariate diet for $21 \mathrm{~d}$, after which they were assigned to one of three dietary treatments if they were healthy and producing an average of $25 \mathrm{~kg} / \mathrm{d}$ or more of milk the last $3 \mathrm{~d}$ of the covariate period. Animals were blocked into groups of three by calving date and randomly assigned to corn silage treatments within calving date blocks. They remained on their respective treatments for $120 \mathrm{~d}$. Fifty-two of the initial 60 cows assigned to dietary treatments completed the study. During the course of the study, two 
Table 2. Composition of grain mixture.

\begin{tabular}{lc}
\hline Ingredient & \% of DM \\
\hline Soyhulls & 36.2 \\
Roasted soybeans & 22.5 \\
Bloodmeal & 7.5 \\
Calcium carbonate & 6.5 \\
Sodium bicarbonate & 5.3 \\
Ca-PFA ${ }^{1}$ & 5.0 \\
Salt & 3.8 \\
Dicalcium phosphate & 3.5 \\
Urea & 3.0 \\
Tallow & 2.5 \\
Dynamate & 1.5 \\
Magnesium oxide & 1.5 \\
Mineral/vitamin premix & \\
\hline
\end{tabular}

${ }^{1} \mathrm{Ca}-\mathrm{PFA}=$ Calcium salts of palm oil fatty acids $-83.5 \%$ fat (Church and Dwight Co., Inc., Princeton, NJ).

${ }^{2} \mathrm{Mineral} /$ vitamin premix contained $12.75 \% \mathrm{Ca}, 4.1 \% \mathrm{Zn}, 3.3 \% \mathrm{Mn}$, $5191 \mathrm{mg} / \mathrm{kg}$ of Fe, $7929 \mathrm{mg} / \mathrm{kg}$ of $\mathrm{Cu}, 386 \mathrm{mg} / \mathrm{kg}$ of I, $61 \mathrm{mg} / \mathrm{kg}$ of Co, $211 \mathrm{mg} / \mathrm{kg}$ of Se, vitamin A at 4,411,102.5 IU/kg, vitamin D at $1,060,164 \mathrm{IU} / \mathrm{kg}$, and vitamin $\mathrm{E}$ at $26,460 \mathrm{IU} / \mathrm{kg}$.

cows were removed from the $36 \mathrm{~F} 30$ treatment due to Johne's disease and death, two cows were removed from the TMF2450 treatment because of toxic mastitis and lameness, and four cows were removed from the TMF2404 treatment because of hardware disease, stifle injury, or death. Cows were milked at 0600 and 1800 $\mathrm{h}$ each day. Milk weights, feed intakes, and health information were recorded daily. Body weight and BCS (scale of 1 to 5 where $1=$ thin to $5=$ fat, Wildman et al., 1982) were taken every 2 wk. Milk samples were taken from the a.m. and p.m. milking on $1 \mathrm{~d}$, every 2 wk, and analyzed for fat, true protein, and SCC (Stearns DHIA, Sauk Center, MN).

Cows were individually fed their assigned diets once per day to allow for 5 to $10 \%$ orts. The diets were fed as a TMR and contained similar ingredients except for corn silage hybrid. Diets were formulated to contain $40 \%$ corn silage on a DM basis and to meet or exceed the nutrient recommendations in the Dairy NRC (1989). Diets were formulated to contain equal concentrations of NDF (28\%), NDF from forage (22\%), NFC, and $\mathrm{CP}(17 \%)$. Alfalfa haylage, corn grain, and the soybean meal/distillers grains ratio (60:40) were varied to achieve the formulation constraints. Nutrient contents of the corn silages used for the formulation were from the mini-silo samples. Ingredient composition of the experimental diets is shown in Table 1, and composition of the grain mix is presented in Table 2 . The covariate TMR contained a mixture of corn silage hybrids routinely fed at the West Central Research and Outreach Center, with other ingredients similar to those used in the experimental diets. Feed samples, orts, and TMR samples were taken on a weekly basis. Ingredient samples were checked for DM on a weekly basis, and diets were adjusted to maintain ingredients at constant percentages of the diet DM. Individual feed ingredient samples were composited every $4 \mathrm{wk}$, and subsamples were used for analysis of nutrient content. Total mixed ration and ort samples were composited every $4 \mathrm{wk}$ and subsamples taken for nutrient analysis and particle sizing using a Penn State Particle Separator (NASCO; Fort Atkinson, WI) with two screens, sizes 0.79 and $1.91 \mathrm{~cm}$. Smaller material passed through the screens to the collection pan.

Sample analyses. Feed and ort subsamples were dried in a $60^{\circ} \mathrm{C}$ forced-air oven and ground in a Wiley mill (Swedesboro, NJ) to pass through a 1-mm screen. Feed and ort samples were analyzed sequentially for $\mathrm{NDF}$ and $\mathrm{ADF}$ using the $\mathrm{ANKOM}^{200}$ fiber system (ANKOM Technology Corporation, Fairport, NY). Sodium sulfite and heat stable $\alpha$-amylase were included in the neutral detergent extraction, and heat stable $\alpha$-amylase was also added during the first two rinses (Hintz and Mertens, 1996). Acid detergent lignin was determined by digesting the $\mathrm{ADF}$ residue in $72 \%$ sulfuric acid (Hintz and Mertens, 1996). Samples were analyzed for ash in a muffle furnace at $500^{\circ} \mathrm{C}$ (AOAC, 1995). Monthly composites were analyzed for CP (NA 2100 Protein Nitrogen Analyzer, ThermoQuest Italia S. p. A., Italy; AOAC, 1995) and ether extract (EE; AOAC, 1995). Neutral detergent insoluble CP (NDICP) was determined after NDF extraction by analyzing the residue for CP. Because sodium sulfite was included in the neutral detergent solution, the NDICP concentration underestimated fiber-bound CP (Van Soest et al., 1991; Licitra et al., 1996), but NDICP was utilized in the calculation of NFC concentration. Starch was determined on feed, orts, and feces. Starch was hydrolyzed with $\alpha$-amylase (Sigma \#A 3306; Sigma Chemical Co., St. Louis, MO) and amyloglucosidase (Sigma \#A 3514). Glucose was assayed using a glucose oxidase kit (Sigma 510 -A) using a plate reader at $450 \mathrm{~nm}$. The NFC concentration was calculated using the following equation:

$$
\begin{aligned}
\mathrm{NFC} & =100-\{(\% \mathrm{NDF}-\% \mathrm{NDICP}) \\
& +\% \mathrm{CP}+\% \mathrm{EE}+\% \mathrm{ash}\} .
\end{aligned}
$$

Lactic acid and VFA concentrations of the silages and haylage were determined by GLC (Erwin et al., 1961).

In vitro true (IVTD) and NDF (IVNDFD) digestibilities of the monthly composite samples of haylage and treatment corn silages were determined after 48 - $h$ incubations with rumen fluid using the ANKOM DAISYI Incubator. Approximately $0.5 \mathrm{~g}$ of sample was weighed into ANKOM nylon bags $(4.5 \times 5.0 \mathrm{~cm}, 57-\mu \mathrm{m}$ pore size $)$ and heat sealed. Samples were presoaked in a mixture of McDougall's buffer (McDougall, 1948) and porcine amylase (Sigma A-3176) for $24 \mathrm{~h}$ to improve repeatabil- 
ity of the IVNDFD measurements by removing starch prior to rumen fluid addition. Samples were subsequently incubated in a mixture of McDougall's buffer and rumen fluid prepared in a 4:1 ratio, with the reducing agents L-cysteine hydrochloride hydrate and sodium sulfite added to the buffer solution. The rumen fluid was collected from a lactating Holstein cow fed a corn silage based TMR and strained through cheesecloth. After $48 \mathrm{~h}$, bags were removed from the rumen fluid and rinsed. The samples were analyzed for NDF by the methods previously described.

The total digestible nutrients at maintenance intake $\left(\mathrm{TDN}_{1 \mathrm{x}}\right)$ for haylage and corn silages were determined using nutrient analysis data and equations listed in the most recent Dairy NRC (2001). The IVNDFD means were used in the $\mathrm{TDN}_{1 \mathrm{x}}$ calculations for each corn silage. The $\mathrm{TDN}_{1 \mathrm{x}}$ and $\mathrm{NE}_{\mathrm{L}}$ at actual observed DMI were determined for the covariate and corn silage treatment diets using the most recent Dairy NRC model (2001).

\section{Digestibility Study}

In March 2001, digestibility of the corn silage diets used in the lactation study was determined. Fifteen cows from each dietary treatment were selected by DIM (ranging from 32 to 179 DIM) to obtain a 107-d average for each treatment. Because calving occurred over a 5mo period, a few cows on each treatment had completed the lactation study but were retained on their respective dietary treatment for inclusion in the digestion study. Samples of the TMR from each dietary treatment were taken for 4 consecutive days. Orts from each cow were sampled $1 \mathrm{~d}$ after starting the TMR sampling and continued for $4 \mathrm{~d}$. Individual daily ort samples were proportionately composited based on daily ort proportions relative to the 4 -d total orts. Starting on d 3 of TMR sample collection, fecal samples were collected over a 3 -d period every 6 to $8 \mathrm{~h}$ to provide 12 fecal samples per cow. Individual cow fecal samples were composited on an equal weight basis and frozen for future analysis. The composite TMR, orts, and fecal samples were dried in a $60^{\circ} \mathrm{C}$ forced-air oven and ground in a Wiley mill to pass through a 1-mm screen. Samples were subsequently analyzed for NDF, CP, and starch and for acid insoluble ash, which was used as an internal marker to determine apparent total-tract DM digestibilities (Van Keulen and Young, 1977).

\section{Statistical Analysis}

Milk production and composition, and feed intake data from the lactation study were analyzed as a randomized complete block design with three corn silage dietary treatments and 20 replicates. Cows were blocked according to calving date. Individual cow data from the covariate period of the study was included in the model. Data from the digestibility study were analyzed as a completely randomized design with the three dietary treatments and 15 replicates. Covariate period data were not included as a model parameter for the digestibility study. The least significant difference method was utilized to compare treatment means when the ANOVA $F$ test was significant. All results are reported as least squares means. Differences among observations were considered significant at $P<0.05$. The procedures in SAS were used for all statistical analyses (SAS, 1999).

\section{RESULTS AND DISCUSSION}

Estimated yield of the TMF2450 corn silage was 19.2 tonne of DM/ha, which was numerically 1.0 and 1.5 tonne/ha greater than TMF2404 and 36F30 hybrids, respectively. The grain-to-stover ratio was numerically lowest for TMF2450 at 0.7 compared to 0.9 for the other hybrids. Previous research has reported lower grainto-stover ratios for some leafy corn hybrids than conventional hybrids (Kuehn et al., 1999; Thomas et al., 2001). The reduced grain-to-stover ratio for the TMF2450 hybrid was expected to cause a reduction in the silage starch percentage; however, starch percentages were similar among the hybrids throughout the lactation trial (Table 3). Grain DM percent was similar for all three hybrids at harvest (57.2 to $59.5 \%$ DM). Stalk, leaves, and tassel portions were 8 to 10 percentage units higher for TMF2450, resulting in numerically higher whole plant DM (35.7\%) compared with 36F30 and TMF2404 (33.6 and 31.0\%, respectively). In situ starch digestibility determined from the mini-silo samples was numerically higher for TMF2450, with approximately 4 percentage units more starch digested than TMF2404 and 8 percentage units more than $36 \mathrm{~F} 30$ (86.2, 82.4, and $78.1 \%$, respectively).

\section{Lactation Study}

Nutrient composition of forages fed during the covariate and treatment period of the lactation study are shown in Table 3. The $\mathrm{TDN}_{1 \mathrm{x}}$ for 36F30, TMF2450, and TMF2404 was almost identical at 70 to $71 \%$, which would be expected as nutrient content of the three corn silages was very similar. Although 36F30 is a conventional hybrid and would be expected to be higher in grain and lower in fiber than leafy hybrids, it contained the same amount of NDF (39\%, DM basis) as the two leafy hybrids. The ADF content of all corn silages was nearly identical (20.2 to 21.5\%). However, lignin content was 0.3 percentage units higher for TMF2450 than 
Table 3. Nutrient composition and ensiling characteristics of the covariate corn silage (COV), alfalfa haylage, and Pioneer 36F30, and Mycogen TMF2450 and TMF2404 corn silages.

\begin{tabular}{|c|c|c|c|c|c|c|}
\hline \multirow[b]{2}{*}{ Composition $^{1}$} & \multicolumn{6}{|c|}{ Ingredient } \\
\hline & $\mathrm{COV}$ & Alfalfa haylage & 36 F30 & TMF2450 & TMF2404 & $\mathrm{SE}^{2}$ \\
\hline $\mathrm{DM}, \%$ & 39.8 & 43.9 & 35.9 & 37.8 & 34.3 & - \\
\hline $\mathrm{TDN}_{1 \mathrm{x}}$ & 70.8 & 62.0 & 71.1 & 70.1 & 70.6 & - \\
\hline NDF, $\%$ & 36.0 & 37.4 & 39.6 & 39.2 & 39.5 & 0.50 \\
\hline $\mathrm{ADF}, \%$ & 20.2 & 26.4 & 20.9 & 21.5 & 21.0 & 0.27 \\
\hline Lignin, \% & 2.6 & 6.5 & $2.5^{\mathrm{b}}$ & $2.8^{\mathrm{a}}$ & $2.5^{\mathrm{b}}$ & 0.08 \\
\hline Starch, \% & 32.5 & 0.2 & 32.6 & 30.5 & 30.4 & 1.01 \\
\hline Ash, \% & 4.1 & 11.3 & $3.6^{\mathrm{c}}$ & $4.2^{\mathrm{b}}$ & $4.5^{\mathrm{a}}$ & 0.08 \\
\hline $\mathrm{CP}, \%$ & 7.0 & 21.6 & 7.0 & 7.1 & 7.3 & 0.15 \\
\hline $\mathrm{EE}, \%$ & 3.1 & 4.2 & 3.0 & 2.9 & 3.2 & 0.27 \\
\hline NFC, \% & 51.1 & 29.0 & 47.7 & 47.9 & 46.5 & - \\
\hline IVTD, \% & - & 80.0 & $72.7^{\mathrm{y}}$ & $72.5^{\mathrm{y}}$ & $74.5^{\mathrm{x}}$ & 0.71 \\
\hline $\begin{array}{l}\text { IVNDFD, } \\
\% \text { of NDF }\end{array}$ & - & 49.4 & 32.3 & 33.8 & 37.1 & 1.61 \\
\hline $\begin{array}{l}\text { Ensiling characteristics } \\
\text { pH }\end{array}$ & & & & & & \\
\hline $\begin{array}{l}\mathrm{pH} \\
\text { Acetate, } \%\end{array}$ & - & $\begin{array}{l}4.64 \\
1.10\end{array}$ & $\begin{array}{l}3.87 \\
1.09\end{array}$ & $\begin{array}{l}4.01 \\
0.63\end{array}$ & $\begin{array}{l}3.98 \\
0.55\end{array}$ & - \\
\hline $\begin{array}{l}\text { Acetate, } \% \\
\text { Propionate, \% }\end{array}$ & - & 0.06 & 0.01 & $\begin{array}{l}0.63 \\
0.003\end{array}$ & $\begin{array}{l}0.55 \\
0.004\end{array}$ & - \\
\hline Isobutyrate, \% & - & 0.004 & 1.09 & $\mathrm{ND}^{3}$ & ND & - \\
\hline Lactate, \% & - & 6.02 & 4.94 & 2.90 & 2.39 & - \\
\hline
\end{tabular}

${ }^{\mathrm{a}, \mathrm{b}}$ Means of experimental corn silages not sharing a common superscript differ $(P<0.05)$.

x,y Means of experimental corn silages not sharing a common superscript differ $(P<0.10)$.

${ }^{1} \mathrm{TDN}_{1 \mathrm{x}}=\mathrm{TDN}$ at maintenance DM intake as calculated by the 2001 Dairy NRC model, EE $=$ ether extract, $\mathrm{NFC}=100-\{(\% \mathrm{NDF}-\% \mathrm{NDICP})+\% \mathrm{CP}+\% \mathrm{EE}+\% \mathrm{ash}\}, \mathrm{NDICP}=$ neutral detergent insoluble CP, IVTD $=$ in vitro true disappearance, IVNDFD $=$ in vitro $\mathrm{NDF}$ disappearance.

${ }^{2}$ Standard error of the mean from analysis of the monthly feed composites of the three experimental corn silages.

${ }^{3}$ Not detected.

for 36F30 and TMF2404. Starch percentage did not differ among the corn silage hybrids. There were no differences in EE among the three corn silage hybrids.

In vitro true digestibility and IVNDFD for the three treatment corn silages are shown in Table 3. The IVTD tended $(P<0.10)$ to be higher $(2$ percentage units) for TMF2404 than 36F30 and TMF2450. The trend towards increased IVTD of TMF2404 reflects its possibly more digestible NDF fraction with TMF2404 being numerically 3.3 and 4.8 percentage units higher in IVNDFD than TMF2450 and 36F30, respectively; however, these numerical differences for IVNDFD were not significant. In a study by Thomas et al. (2001), even greater variation for in vitro digestibility (4.2 percentage units IVTD and 9.6 percentage units IVNDFD) was found between conventional and leafy corn silage hybrids.

Diet DM concentration was similar across all diets and averaged $51.3 \%$ (Table 4 ). The production $\mathrm{NE}_{\mathrm{L}}$, based on actual average DMI $(4.1 \times$ maintenance $)$ for the lactation study (Table 4), was similar for the three corn silage diets and averaged $1.56 \mathrm{Mcal} / \mathrm{kg} \mathrm{DM}$. The NDF from forage in the 36F30, TMF2450, and TMF2404 diets ranged from 20.3 to $22.1 \%$. Total NDF, and NDF from forage and ADF concentrations in the diets were at or below the initial formulation levels, but above 2001 Dairy NRC recommendations (2001). These deviations in fiber levels may have resulted from the formulation being based on mini-silo samples, analyzed by near-infrared spectroscopy, compared with the monthly silage feed samples collected during the lactation trial and analyzed by wet chemistry. Concentrations of $\mathrm{NDF}, \mathrm{ADF}$, lignin, ash, EE, and starch were similar across diets.

Particle distribution on the Penn State Particle Separator was similar among the three corn silage diets, averaging $2.4 \%$ on the top screen, $35.2 \%$ on the middle screen, and $62.4 \%$ in the pan. Ort particle size distribution was also similar among dietary treatments and appeared to be the same as the TMR particle size distribution, indicating cows were not sorting the TMR while eating.

Intakes of DM, CP, and NDF were not different across the three corn silage diets (Table 5). Similarly, neither Kuehn et al. (1999) or Thomas et al. (2001) observed differences in DMI between diets containing conventional and leafy hybrids. In contrast, Clark et al. (2002) reported $0.9 \mathrm{~kg} / \mathrm{d}$ higher DMI for diets containing a leafy corn silage hybrid as opposed to a conventional hybrid. 
Table 4. Nutrient composition of diets containing 40\% covariate (COV), Pioneer 36F30, and Mycogen TMF2450 and TMF2404 corn silages.

\begin{tabular}{lrrrr}
\hline & \multicolumn{3}{c}{ Diet } \\
\cline { 2 - 5 } Item $^{1}$ & COV & 36 F30 & TMF2450 & TMF2404 \\
\hline DM, \% & 52.3 & 51.2 & 53.2 & 49.4 \\
\cline { 2 - 4 } & & & DM basis & 73.7 \\
TDN $_{1 \times}, \%$ & 71.9 & 73.3 & 1.6 & 72.6 \\
NE $_{\mathrm{L}}$, Mcal/kg & 2.1 & 1.6 & 27.3 & 1.6 \\
NDF, \% & 28.1 & 28.0 & 20.3 & 28.4 \\
Forage NDF, \% & 21.6 & 21.4 & 14.9 & 22.1 \\
ADF, \% & 15.9 & 15.2 & 2.2 & 15.7 \\
Lignin, \% & 2.6 & 2.2 & 7.5 & 8.3 \\
Ash, \% & 8.1 & 17.3 & 17.2 & 16.9 \\
CP, \% & 17.9 & 4.4 & 4.3 & 4.4 \\
EE, \% & 4.4 & 26.6 & 26.8 & 25.4 \\
Starch, \% & 22.8 & 43.3 & 44.3 & 43.0 \\
NFC, \% & 42.8 & & & \\
\hline
\end{tabular}

${ }^{1} \mathrm{TDN}_{1 \mathrm{x}}=\mathrm{TDN}$ at maintenance DMI as calculated by the 2001 Dairy NRC model, $\mathrm{NE}_{\mathrm{L}}=3.0 \times$ maintenance intake for COV and $4.1 \times$ maintenance intake for 36F30, TMF2450 or TMF2404 corn silage diets as calculated by the 2001 Dairy NRC computer model, EE $=$ ether extract, NFC $=100-\{(\%$ NDF $-\%$ NDICP $)+\% \mathrm{CP}+$ $\% \mathrm{EE}+\%$ ash $\}$, NDICP = neutral detergent insoluble CP.

Milk yield and composition data are shown in Table 5 . There was no difference in milk yield of cows fed the three corn silage diets. Lactation curves were similar for all corn hybrids (data not shown). Kuehn et al. (1999) and Ballard et al. (2001) also reported no difference in milk yields when leafy and conventional corn silage hybrids were fed to lactating cows. In contrast, cows fed diets containing leafy corn silage hybrids produced 1.5 and $1.4 \mathrm{~kg} / \mathrm{d}$ more milk than cows fed conventional hybrids in two other studies (Thomas et al., 2001; Clark et al., 2002). Milk fat and protein yields were not different among treatments, ranging from 1.24 to $1.36 \mathrm{~kg} / \mathrm{d}$ for milk fat and 1.01 to $1.12 \mathrm{~kg} / \mathrm{d}$ for true milk protein. Clark et al. (2002) reported a $0.05 \mathrm{~kg} / \mathrm{d}$ increase in milk fat production for cows fed a leafy corn silage diet compared with a diet containing conventional corn silage. In contrast, Thomas et al. (2001) reported a trend toward greater protein yield from cows fed a leafy corn silage diet. Yields of $4.0 \% \mathrm{FCM}$ were not different at $35.4,32.7$, and $33.5 \mathrm{~kg} / \mathrm{d}$ for $36 \mathrm{~F} 30$, TMF2450, and
TMF2404, respectively. Other studies have also reported no improvement (Kuehn et al., 1999; Bal et al., 2000; Ballard et al., 2001) in FCM production from feeding leafy corn silage hybrids, whereas two studies did find an increase in FCM (Thomas et al., 2001; Clark et al., 2002). Milk SCC were similar among treatment groups (data not shown).

Cows fed 36F30, TMF2450, and TMF2404 had an average BW of 592, 589, and $613 \mathrm{~kg}$, respectively, throughout the lactation study. The average weekly change in BW over the 17-wk lactation study for cows fed TMF2450 and 36F30 diets was $-0.50 \mathrm{~kg} / \mathrm{wk}$, whereas cows fed TMF2404 diets had a small positive average BW gain. Cows fed 36F30, TMF2450, and TMF2404 diets all had normal BW curves, with small decreases in BW occurring in early lactation followed by slow gains throughout the rest of the study. The average BCS of cows was 2.87 , and no treatment differences were found.

Table 5. Milk yield and composition, and nutrient intake of cows fed diets containing $40 \%$ Pioneer $36 \mathrm{~F} 30$, and Mycogen TMF2450 and TMF2404 corn silages.

\begin{tabular}{lccccc}
\hline & \multicolumn{5}{c}{ Diet } \\
\cline { 2 - 4 } Item & 36 F30 & TMF2450 & TMF2404 & SE & $P$ value \\
\hline DMI, kg/d & 24.1 & 23.1 & 24.6 & 0.83 & 0.45 \\
CP intake, kg/d & 4.1 & 4.0 & 4.1 & 0.16 & 0.84 \\
NDF intake, kg/d & 6.7 & 6.3 & 6.8 & 0.26 & 0.36 \\
Milk yield, kg/d & 37.4 & 35.3 & 36.8 & 1.22 & 0.50 \\
4.0\% FCM, kg/d & 35.4 & 32.7 & 33.5 & 1.35 & 0.35 \\
Milk fat yield, kg/d & 1.36 & 1.24 & 1.26 & 0.06 & 0.35 \\
Milk protein yield, kg/d & 1.12 & 1.01 & 1.07 & 0.04 & 0.23 \\
Milk fat, \% & 3.55 & 3.41 & 3.58 & 0.09 & 0.44 \\
Milk protein, \% & 2.97 & 2.87 & 2.95 & 0.05 & 0.39 \\
\hline
\end{tabular}


Table 6. Digestibility study results for milk yield, nutrient intake, and apparent digestibilities of diets containing 40\% Pioneer 36F30, and Mycogen TMF2450 and TMF2404 corn silages.

\begin{tabular}{|c|c|c|c|c|c|}
\hline \multirow[b]{2}{*}{ Item } & \multicolumn{3}{|c|}{ Diet } & \multirow[b]{2}{*}{$\mathrm{SE}$} & \multirow[b]{2}{*}{$P$ value } \\
\hline & $36 \mathrm{~F} 30$ & TMF2450 & TMF2404 & & \\
\hline Milk, kg/d & 36.7 & 33.7 & 36.0 & 2.15 & 0.49 \\
\hline DMI, $\mathrm{kg} / \mathrm{d}$ & 25.7 & 24.4 & 25.9 & 1.38 & 0.71 \\
\hline CP intake, $\mathrm{kg} / \mathrm{d}$ & 4.3 & 4.5 & 4.6 & 0.24 & 0.77 \\
\hline NDF intake, $\mathrm{kg} / \mathrm{d}$ & 6.8 & 6.5 & 6.9 & 0.37 & 0.69 \\
\hline Starch intake, kg/d & 8.1 & 7.6 & 8.0 & 0.42 & 0.74 \\
\hline DM digestibility, \% & $72.0^{\mathrm{a}}$ & $73.4^{\mathrm{a}}$ & $68.7^{\mathrm{b}}$ & 0.86 & $<0.01$ \\
\hline CP digestibility, \% & $72.9^{\mathrm{b}}$ & $76.6^{\mathrm{a}}$ & $69.7^{\mathrm{c}}$ & 1.04 & $<0.01$ \\
\hline NDF digestibility, \% & $46.2^{\mathrm{b}}$ & $50.5^{\mathrm{a}}$ & $41.5^{\mathrm{c}}$ & 1.50 & $<0.01$ \\
\hline Starch digestibility, \% & 97.6 & 98.0 & 97.7 & 0.32 & 0.44 \\
\hline
\end{tabular}

${ }^{\mathrm{a}, \mathrm{b}, \mathrm{c}}$ Means not sharing a common superscript differ $(P<0.05)$.

\section{Digestibility Study}

Milk yield and DMI of cows fed the three corn silage diets were not different during the digestibility study (Table 6), as was expected from the similar milk yield and DMI results during the lactation study. The similarity in DMI and diet compositions resulted in similar intakes of $\mathrm{CP}, \mathrm{NDF}$, and starch (Table 6). Apparent DM digestibility was lower for the TMF2404 diet than 36F30 or TMF2450 diets. Crude protein and NDF digestibilities were highest for the TMF2450 diet, intermediate for the 36F30 diet, and lowest for the TMF2404 diet. Because feed intake was not different among the three corn silage diets, we assume that rates of digesta passage were similar among treatments, and differences in rumen or lower gut retention times probably did not account for the observed changes in digestibility among the experimental diets. Differences among the corn silage diets for nutrient digestibilities may have resulted from intrinsic differences among the corn silages or associative effects related to the small differences among diets for ingredient proportions. The higher apparent NDF digestibility of the TMF2450 diet did not coincide with the corn silage IVNDFD data (Table 3) because TMF2450 corn silage IVNDFD was not significantly different compared with $36 \mathrm{~F} 30$ and TMF2404. However, the TMF2450 diet contained less alfalfa haylage and more distillers grains than the other two diets. This diet composition probably resulted in the substitution of less digestible fiber from haylage for more digestible fiber from distillers grains. Apparent total-tract starch digestibility was not different between treatments and averaged $97.8 \%$ (Table 6). The numerically lower in situ 16-h starch digestibility for 36F30 (78.1\%) compared with TMF2450 (86.2\%) and TMF2404 (82.4\%) mini-silo corn silages may indicate that rumen retention times were sufficiently long for the high-grain hybrid to reach the same extent of digestion as the leafy hybrids, or that intestinal digestion compensated for lower ruminal starch digestion of 36F30. In contrast, Bal et al. (2000) observed improved in vivo total-tract starch digestibility for a leafy corn silage containing diet.

It should be noted that for the comparisons of lactation and digestibility responses in the current study with previously published leafy vs. conventional corn silage hybrid evaluation trials, in no case were the same corn hybrids utilized in the previous studies as those included in the current study. Therefore, general conclusions regarding the impact of the leafy trait in corn silage hybrids on utilization by dairy cows must be made with caution. Effects of corn genetic background on expression of the leafy trait are confounded with lactation trials.

\section{CONCLUSIONS}

The corn silage hybrids used in this study had similar nutrient composition. The diet containing TMF2450 had higher apparent total-tract $\mathrm{CP}$ and NDF digestibility than diets containing 36F30 or TMF2404. However, these differences in digestibilities did not result in significant improvement in lactation performance of Holstein dairy cows. While the leafy trait did not confer any advantages in the current corn silage utilization study, comparisons of corn hybrids within individual studies must be viewed with caution because most experiments (including the current study) do not compare corn hybrids of similar genetic backgrounds, with the exception of the genetic trait(s) of interest. Therefore, conclusions concerning the potential superiority of one corn hybrid type over others should be based on multiple comparisons.

\section{ACKNOWLEDGMENTS}

The authors would like to thank the field crew and farm attendants at the West Central Research and Out- 
reach Center for their participation in this study. Authors also express their thanks to Mycogen Seeds (Indianapolis, IN) for the donation of product and partial funding of this project.

\section{REFERENCES}

Association of Official Analytical Chemists. 1995. Official Methods of Analysis. 16th ed. AOAC, Arlington, VA.

Bal, M. A., R. D. Shaver, H. Al-Jobeile, J. G. Coors, and J. G. Lauer. 2000. Corn silage hybrid effects on intake, digestion, and milk production by dairy cows. J. Dairy Sci. 83:2849-2858.

Ballard, C. S., E. D. Thomas, D. S. Tsang, P. Mandebvu, C. J. Sniffen, M. I. Endres, and M. P. Carter. 2001. Effect of corn silage hybrid on dry matter yield, nutrient composition, in vitro digestion, intake by dairy heifers, and milk production by dairy cows. J. Dairy Sci. 84:442-452.

Barriere, Y., J. C. Emile, R. Traineau, and Y. Hebert. 1995. Genetic variation in the feeding efficiency of maize genotypes evaluated from experiments with dairy cows. Plant Breed. 114:144-148.

Clark, P. W., S. Kelm, and M. I. Endres. 2002. Effect of feeding a corn hybrid selected for leafiness as silage or grain to lactating dairy cattle. J. Dairy Sci. 85:607-612.

Erwin, E. S., G. T. Marco, and E. M. Emery. 1961. Volatile fatty acid analysis of blood and rumen fluid by gas chromatography. J. Dairy Sci. 44:1768.

Hintz, R. W., and D. R. Mertens. 1996. Effects of sodium sulfite on recovery and composition of detergent fiber and lignin. J. AOAC Int. 79:16.
Kuehn, C. S., J. G. Linn, D. G. Johnson, H. G. Jung, and M. I. Endres. 1999. Effect of feeding silages from corn hybrids selected for leafiness or grain to lactating dairy cattle. J. Dairy Sci. 82:2746-2755.

Licitra, G., T. M. Hernandez, and P. J. Van Soest. 1996. Standardization of procedures for nitrogen fractionation of ruminant feeds. Anim. Feed Sci. Technol. 57:347-358.

McDougall, E. I. 1948. Studies on ruminant saliva: 1. The composition and output of sheep's saliva. Biochem. J. 42:99-109.

National Research Council. 1989. Nutrient Requirements of Dairy Cattle. 6th rev. ed. Natl. Acad. Sci., Washington, DC.

National Research Council. 2001. Nutrient Requirements of Dairy Cattle. 7th rev. ed. Natl. Acad. Sci., Washington, DC.

Oba, M., and M. S. Allen. 1999. Effects of brown midrib 3 mutation in corn silage on dry matter intake and productivity of high yielding dairy cows. J. Dairy Sci. 82:135-142.

SAS User's Guide: Statistics, Version 8.1. 1999. SAS Inst., Inc., Cary, NC.

Thomas, E. D., P. Mandebvu, C. S. Ballard, C. J. Sniffen, M. P. Carter, and J. Beck. 2001. Comparison of corn silage hybrids for yield, nutrient composition, in vitro digestibility, and milk yield by dairy cows. J. Dairy Sci. 84:2217-2226.

Van Keulen, J., and B. A. Young. 1977. Evaluation of acid-insoluble ash as a natural marker in ruminant digestion studies. J. Anim. Sci. 44:282.

Van Soest, P. J., J. B. Robertson, and B. A. Lewis. 1991. Methods for dietary fiber, neutral detergent fiber, and nonstarch polysaccharides in relation to animal nutrition. J. Dairy Sci. 74:35833597.

Wildman, E. E., G. M. Jones, P. E. Wagner, R. L. Boman, H. F. Troutt, and T. N. Lesch. 1982. A dairy cow body condition scoring system and its relationship to selected production characteristics. J. Dairy Sci. 65:495-501. 